Journal of Social Sciences 3 (2): 94-105, 2007

ISSN 1549-3652

(C) 2007 Science Publications

\title{
Breaking out: The Dynamics of Immigrant Owned Businesses
}

\author{
Shahamak Rezaei \\ Roskilde University, Department of Society \& Globalization, Denmark
}

\begin{abstract}
As far as integration policy in a Danish context is concerned a phenomenon have been observed during the last decade: Immigrant businesses are spreading rapidly in the country, dominating certain business lines in deprived inner city areas. According to registry and survey data, most immigrant businesses - and particularly those owned by immigrants from less developed countries in Asia, the Middle East and Africa - are tiny self-employment units in which profits are low and working hours long for the owners. They occupy mainly traditional small firm dominated business lines, which the majority population tend to abandon anyway. Only seldom do they grow into larger firms and shift to more advanced and profitable business fields. This pattern, however, seems to be slowly changing in that some well-educated first and second generation immigrant groups (among them particularly women) have the potential to start and run more advanced and profitable businesses outside the traditional ethnic business lines and outside minority dominated inner city areas. Key determinants in this process seem to be owner qualifications, network patterns, financial resources and cross border business relations.
\end{abstract}

Key words: Immigrant businesses, ethnic economy, break out, marginal business fields, comparative study of immigrant groups.

\section{INTRODUCTION}

Migration leads, often with significant time lag, to formation of immigrant businesses in recipient countries. In its narrowest sense, an immigrant business may simply be defined as "a firm owned by an immigrant". As such, the phenomenon is interesting only from the point of view of immigrants themselves, opening an alternative route into the economic life of their new societies. It has interest from a quantitative point of view as immigrants may influence the venture creation process in their new economies due to differences in the entrepreneurship levels of immigrants and the majority population. Immigrant businesses are, however, also interesting from a qualitative point of view. They are usually heavily infused with culturalethnic elements influencing what they produce, how they are managed, the composition of the staff, how they relate to other businesses, and how they build their international relationships. In other words, they add variation and international outlook to the economy of the recipient country, as a consequence of the opportunity structure created by a combination of several factors such as the specific welfare state regime, the specific structure of the market, the character and the scope of the relation between immigrant populations and the institutions (be it formal or informal) of the host country and the dynamics of the specific immigrant populations ${ }^{[1]}$.

Immigrant businesses are not distributed randomly in the economy of the recipient country. They are predominantly small-scale family firms, clustered in specific business lines and urban areas ${ }^{[2]}$. This reflects the competitive advantages they enjoy in certain business fields compared to businesses owned by the majority population. Competitive advantages for immigrant businesses vis-à-vis the market are significant for goods with a significant ethnic component such as clothes and food. This is particularly true in immigrant dense areas where the "home market" provides immigrants with better business opportunities than entrepreneurs from the majority population due to co-ethnic trust and communication mechanisms. However, it also applies to immigrant businesses which in culture loaded fields deals predominantly with the majority population, because these customers may find that they are more convincing and competent producers or traders of such products $^{[3]}$. Immigrant businesses may also benefit from co-ethnic solidarity and resource mobilization which influence how they get started, with whom they do business, and the way employment patterns are shaped. Immigrant groups often choose to employ and do business with co-ethnics because trust relations are easier to build up with those of shared cultural backgrounds and because they are, as a group, under pressure from their new society and in need of in-group solidarity in order to cope with that pressure ${ }^{[4]}$.

The focus in this paper is on breaking-out mechanisms vis-à-vis business lines using the Danish situation as its empirical basis. We want to document (which can be done more accurately in Denmark than in 
most other countries through registry analysis) that immigrant businesses are generally less profitable than the personally owned businesses of the majority population and not a route to growing and prospering businesses. Further, through a comparison of five selected immigrant groups, studied through registry analysis as well as survey data, we want to trace their different strategies, according to self-employment and business development and their ability to make firms grow, restructure and relocate. Finally we want to identify determinants that influence breaking-out patterns and potentials.

As our focus is on breaking-out mechanisms we apply the immigrant business concept rather than the more narrow ethnic business one. Our focus is not only on immigrant businesses which succeed in growing on the basis of ethnic characteristics and relationships, but also on businesses that assimilate into the mainstream economy by abandoning ethnic traits apart from that of immigrant ownership.

\section{A MODEL OF IMMIGRANT BUSINESS BREAKING OUT FROM MARGINAL BUSINESS FIELDS}

Taken together, the fragments of evidence from the USA, Britain and East Asia ${ }^{[5]}$ illustrate that immigrant businesses sometimes do start to grow, change strategies, and break out of enclaved immigrant areas. Such change seems to take place at the expense of the ethnic character of these businesses. Their rooting in the ethnic community is relaxed, but immigrant ownership is retained, as are often the close trading relationships with immigrant businesses, even across borders.

Ram and Jones have elaborated a model which attempts to capture the market break-out process, suggesting two basic dimensions: local vs. non-local, and ethnic vs. non-ethnic ${ }^{[6]}$. These dimensions have been mapped into four quadrants:

Local \& Ethnic: Enclosed immigrant businesses, mainly in the retail and service lines, trapped in crowded immigrant dominated areas, serving predominantly immigrants,

Non-Ethnic \& Local: Growing immigrant businesses in low order retail and service lines, serving the needs of the majority population and locating inside immigrant dominated areas,

Ethnic \& Non-Local: Serving mainly immigrants but operating in a wider territory (the city, the region, the nation) such as wholesalers and manufacturers that distribute and produce ethnic goods or goods for immigrant firms,

Non-Ethnic \& Non-Local: The ultimate breaking-out form, confined neither by customer ethnicity or locality.
Encompasses manufacturers and high-order retail, wholesale and services for the open market.

The bulk of UK immigrant businesses are in the A and $B$ positions: relatively few are found in the $C$ and $D$ positions where profit levels generally are higher.

This model seems to capture important sides of the breaking-out process, but is in need of some elaboration. "Ethnic" remains a rather unclear concept in that ethnic identity depends on ongoing social construction processes and in that some people find that they have two or more ethnic identities (e.g. a religious identity combined with the identity stemming from their country of origin, cf. Light's study of the business activities of different religious Iranian groups in Los Angeles $^{[7]}$. Moreover the concept combines individualistic (identity) and social dimensions (relationship and social action) as well as different market aspects such as the ethnic character of firms in the supply chain and the ethnic content of consumer goods (which also change in the course of time: pizza's are, for instance, no longer seen as Italian food but rather as non-ethnic food of Italian origin). The "NonLocal" category is also ambiguous in that it seems both to refer to the location of businesses and markets and in that the authors talk only about levels within the British national economy while ethnic businesses may well reach out to the international level. But, taken together, the model is a useful departure for studies of breakingout processes. It points to the need to study the local vs. non-local dimension as well as business line structuring and the shaping of business relationships along ethnic lines. Moreover, there is an in-build firm size dimension in the model, in that position $A$ is predominantly small-scale while position $\mathrm{D}$ is predominantly medium- and large-scale.

In the subsequent empirical sections on immigrant businesses in Denmark, we shall therefore look in particular at four dimensions: 1) business line agglomeration and dynamics, 2) firm-size structure and dynamics, 3) location of immigrant businesses, and 4) the shaping of immigrant business owners' relationships.

\section{EMPIRICAL EVIDENCE: COMBINING REGISTRY AND SURVEY DATA}

The results are based on two data sources: Registry data and a survey among 279 immigrant business owners in the greater Copenhagen area.

The registry data consists of micro-data on the socio-economic characteristics of the entire population living in Denmark in 1982, 1989, 1996 and 1997-2002 and all privately owned firms in Denmark 1992-1996 and 1997-2002. The database, which is maintained and available at Statistics Denmark, links information from various official statistical registers. 
The data includes information on individuals by socio-economic status, place of birth, place of work, age, gender, education, income, source of income, employment, periods of unemployment, tax payments, ownership of house or business, citizenship, date of immigration, date of emigration, date of death, marital status, number of children and a wealth of other variables. The same type of information can also be obtained on parents, spouses and in-laws with the possibility of cross generation information where parents or spouses live, or have lived, in Denmark.

The data also includes registry information about firms, for example, owners' place of birth, citizenship status, date of a firm's establishment, date of immigration (if immigrant), number of employees and their place of birth and citizenship status, turnover, exports, tax payments, business line, number of businesses, level of education, socio-economic status before starting up as self-employed, date of shutdown (when relevant), socio-economic status following a shutdown, and a great many other variables.

In this study we have used a cross-national sample of all immigrants and their descendants (between the ages of 18-59 years) living in Denmark in 1982, 1989, 1996 or 2002 and a 5 per cent control group of native Danes for the first three years and a 10 per cent control group of native Danes for the years 1997-2002.

The registry analysis of firms is based on all immigrant owned ones (with owners in the age group 18-59 years) and a 5 per cent control group of firms owned by native Danes for the period 1992-1996. For calculation purposes, individual observations taken from the 5 per cent control group have been weighted in order to represent the true distribution across the total population.

A questionnaire survey was carried out to supplement the registry based analysis, e.g. on intraand inter-ethnic business owner networks which cannot be studied satisfactorily by registry data. The questionnaire survey response rate was 40.9 per cent (279 respondents out of a sample of 682 business owners, interviewed between November 1998 and May 1999). The sample population was drawn from a total number of 2,329 business owners in 1998, who originated from five selected countries of origin, and were living in Copenhagen and its surrounding suburbs (using individual-based ID numbers). The ID numbers were then combined with the firm's registration at Statistics Denmark. The five countries in question are (in alphabetical order): China (PRC, Taiwan and Vietnam), Iran, Pakistan and Turkey, the former Yugoslavia.

The background for the selection of the five groups was as follows. Pakistanis, Turkish and ExYugoslavians were selected because they are the three major groups of immigrants from the late 1960s when labour immigration to Denmark was still possible. An additional reason is the significant difference in the self-employment rate for the three groups, particularly between Pakistanis and Ex-Yugoslavians who have almost the same immigration history and population size. Chinese were selected because they were reputed for having a high self-employment rate combined with a strong specialisation in catering. Iranians we selected because they seemed to have a higher educational level than the other groups and because their selfemployment rate has increased significantly during the 1990s (from $10,6 \%$ in 1989 to $29,3 \%$ in 1996). All five groups encompass all immigrants from the selected countries whether or not they have become Danish citizens.

Selection of the 682 respondents was based on a stratification methodology. Initially, 10 business owners were chosen from each combination of business line and national origin. A sample size of 20 represented Turkey, as many immigrants from Turkey are of Kurdish origin, and have different motivations/backgrounds for setting up a business. The selection was furthermore stratified into twelve business-lines, structured in such a way that business lines with a high share of immigrant business owners were exposed, e.g. splitting service firms into cleaning ones and others. Finally the survey population was limited geographically to the greater Copenhagen area. This was done due to practical reasons as well as the fact that the explorative study had shown that the only significant difference between the capital and provincial regions of Denmark consists of a time lag in the development of the business structure.

An analysis of the response/non-response levels for the different immigrant groups and their lines of business, based on background data available for both groups through registry data, only revealed insignificant variation which could be explained as a random, nonsystematic deviation.

All tables and figures in the paper have been produced by the authors, and are based on either data provided by Statistics Denmark or survey data.

\section{ARE IMMIGRANT BUSINESSES IN DENMARK CAPTURED IN MARGINAL BUSINESS FIELDS?}

In the following passage we will take a glance at what business fields different groups of immigrants have placed there businesses in on a basis of empirical data. We will demonstrate the differences in gross income between the different immigrant groups and the 
natives, a comparison with business lines between natives and the immigrant groups respectively, the impact of different variables for change in the business line, a comparison between firm size, the distribution of turnover, the extend to which the businesses are places in areas with a low or high level of migrants, what financial and social networks immigrant entrepreneurs participate in, and finally to what extent different determinants have importance for the possibilty to change business line from typical immigrant business lines to mainstream business lines.

Being an entrepreneur can be expected to involve long working hours at least in the first years. Thus there must be advantages that compensate for this. The question appears: why do some immigrants become self-employed in a society like the Danish where most immigrants can receive welfare benefits without it having any impact on their possibility to uphold their residence permit? One should expect income aspirations and the desire to be independent of employers to be the key motives, combined with blocked opportunities at the general labour market. In that case it seems reasonable to expect self-employed to earn at least as much as welfare beneficiaries and normally also more than wage earners. The following table shows that there is a gap between the income for self employed and wage earners.

Table 1 shows the differences in gross income per capita for the five immigrant groups compared to native Danes. The three columns of the table represent three different socio-economic categories.

The table demonstrates that the expectancy of a relatively high income for self-employed is met for the native Danes, but not for the five selected immigrant groups. On average wage earners from immigrant groups earn considerably less than what the native Danes earn, mainly because a larger part af them is in lower paid jobs. Also self-employed immigrants earn less than native wage earners.

Taken together, the table demonstrates that it is not on average economically advantageous for immigrants to become self-employed. This impression is confirmed by comparison of the Ex-Yugoslavian and Pakistani minorities which have followed quite different income strategies since about 1980. Pakistanis have increasingly shifted from being wage-earners to becoming self-employed, while only few ExYugoslavians have followed this pattern. This has not resulted in higher incomes for the Pakistani group. On the contrary, Ex-Yugoslavians earn more than Pakistanis in all of the three socio-economic categories. Looking at the income difference between individuals of Iranian national background and Turks, their income across different socioeconomic groups is almost alike in spite of the big difference of educational merits, representing two ends of a continuum.

Without the economic incentive to have business in Denmark, we must expect immigrants to be very keen on their possibilities to break out from the business lines with low yield.

Table 1: gross-income (DKK) for Adults (18-65 year old) per Capita by Socio-economic Status and Country of Origin, Denmark 2002

\begin{tabular}{lccc}
\hline \multicolumn{1}{c}{$\begin{array}{c}\text { National } \\
\text { origin }\end{array}$} & $\begin{array}{c}\text { Self- } \\
\text { employed }\end{array}$ & Wage Earner & Un-employed \\
\hline Iran & 157,274 & 235,093 & 120,492 \\
Pakistan & 194,738 & 198,255 & 117,390 \\
Former & 224,737 & 230,512 & 125,212 \\
Yugoslavia & 164,784 & 196,639 & 125,503 \\
Turkey & 153,151 & 199,312 & 126,289 \\
China ea. & 315,791 & 269,436 & 154,111 \\
\hline Denmark &
\end{tabular}

Source: Statistics Denmark, own calculation.

\section{COMPARISON OF IRANIAN, PAKISTANI, TURKISH, EX-YUGOSLAVIAN AND CHINESE BUSINESSES IN DENMARK}

In the following we will take a glance at the differences among the five Danish immigrant groups according to characteristics in their business lines, employment structure, location of businesses, networks etc. This has the purpose to find resemblances and differences between the groups that can lead to an understanding of what determinants are vital to break out for all and for specific groups.

\section{BUSINESS LINE AND FIRM SIZE}

Table 2 shows the number of businesses in the selected business lines for the five immigrant groups.

The table shows that in each group there is a tendency towards the concentration of firms in certain business lines. Furthermore, the table indicates a complete absence of Chinese business owners in two of the business lines: "Transportation" and "Cleaning". When looking at the business line "Service" a difference between Pakistanis and Ex-Yugoslavians appears. The latter is over-represented here. The Pakistani group, however, has the highest representation in the lowprofit-margin business line of "Supermarkets, kiosks, etc.", which is known for its hard working environment and long working hours. This contributes to the explanation of the income differerences between the two groups shown in the previous table. 
Table 2: Number of Family Businesses $(\mathrm{N}=168,669)$ distributed by Business line and Owner's Country of Origin, Denmark 1996

\begin{tabular}{|c|c|c|c|c|c|c|c|}
\hline & Iran & Pakistan & $\begin{array}{c}\text { Former } \\
\text { Yugoslavia }\end{array}$ & Turkey & China ea. & Denmark & $\begin{array}{c}\text { Other } \\
\text { countries }\end{array}$ \\
\hline \multirow{2}{*}{ Restaurants } & 48 & 14 & 5 & 102 & 48 & 420 & 113 \\
\hline & $6.4 \%$ & $1.4 \%$ & $1.7 \%$ & $5.8 \%$ & $7.9 \%$ & $0.3 \%$ & $1.5 \%$ \\
\hline Cafeteria, barbecues & 167 & 21 & 18 & 248 & 189 & 1240 & 276 \\
\hline etc. & $22.4 \%$ & $2.1 \%$ & $6.1 \%$ & $14.1 \%$ & $31.1 \%$ & $0.8 \%$ & $3.7 \%$ \\
\hline \multirow{2}{*}{ Food \& Nutrition } & 37 & 135 & 13 & 171 & 17 & 940 & 235 \\
\hline & $5.0 \%$ & $13.7 \%$ & $4.4 \%$ & $9.7 \%$ & $2.8 \%$ & $0.6 \%$ & $3.2 \%$ \\
\hline Supermarkets, & 65 & 247 & 15 & 142 & 20 & 560 & 205 \\
\hline Kiosks etc. & $8.7 \%$ & $25.0 \%$ & $5.1 \%$ & $8.0 \%$ & $3.3 \%$ & $0.4 \%$ & $2.8 \%$ \\
\hline \multirow{2}{*}{ Special Retail Shops } & 53 & 31 & 7 & 41 & 22 & 6440 & 466 \\
\hline & $7.1 \%$ & $3.1 \%$ & $2.4 \%$ & $2.3 \%$ & $3.6 \%$ & $4.1 \%$ & $6.3 \%$ \\
\hline Trade \& Agencies & 35 & 30 & 19 & 41 & 27 & 5980 & 600 \\
\hline etc. & $4.7 \%$ & $3.0 \%$ & $6.5 \%$ & $2.3 \%$ & $4.4 \%$ & $3.8 \%$ & $8.1 \%$ \\
\hline \multirow{2}{*}{ Cleaning } & 1 & 3 & 10 & 11 & 0 & 2120 & 146 \\
\hline & $0.1 \%$ & $0.3 \%$ & $3.4 \%$ & $0.6 \%$ & $0.0 \%$ & $1.4 \%$ & $2.0 \%$ \\
\hline \multirow{2}{*}{ Transportation } & 6 & 15 & 12 & 6 & 0 & 3800 & 97 \\
\hline & $0.8 \%$ & $1.5 \%$ & $4.1 \%$ & $0.3 \%$ & $0.0 \%$ & $2.4 \%$ & $1.3 \%$ \\
\hline \multirow{2}{*}{ Service } & 71 & 32 & 55 & 80 & 22 & 30500 & 1655 \\
\hline & $9.5 \%$ & $3.2 \%$ & $18.8 \%$ & $4.5 \%$ & $3.6 \%$ & $19.4 \%$ & $22.3 \%$ \\
\hline \multirow{2}{*}{ Manufacturing } & 12 & 1 & 6 & 6 & 11 & 4100 & 217 \\
\hline & $1.6 \%$ & $0.1 \%$ & $2.0 \%$ & $0.3 \%$ & $1.8 \%$ & $2.6 \%$ & $2.9 \%$ \\
\hline \multirow{2}{*}{ Others/NA } & 252 & 460 & 133 & 916 & 252 & 100740 & 3418 \\
\hline & $33.7 \%$ & $46.5 \%$ & $45.4 \%$ & $51.9 \%$ & $41.4 \%$ & $64.2 \%$ & $46.0 \%$ \\
\hline \multirow{2}{*}{ Total } & 747 & 989 & 293 & 1764 & 608 & 156840 & 7428 \\
\hline & $100.0 \%$ & $100.0 \%$ & $100.0 \%$ & $100.0 \%$ & $100.0 \%$ & $100.0 \%$ & $100.0 \%$ \\
\hline
\end{tabular}

Source: Statistics Denmark, own calculation

Table 3: Number of Family Businesses, Distributed by Number of Employees and Owner's Country of Origin, 1996 $(\mathrm{N}=168,669)$

\begin{tabular}{|c|c|c|c|c|c|c|c|c|}
\hline $\begin{array}{l}\text { Number of } \\
\text { Employees }\end{array}$ & Iran & Pakistan & $\begin{array}{c}\text { Former } \\
\text { Yugoslavia }\end{array}$ & Turkey & China & Denmark & $\begin{array}{l}\text { Other } \\
\text { countries }\end{array}$ & Total \\
\hline \multirow{2}{*}{ None } & 5 & 23 & 1 & 44 & 12 & 1,920 & 75 & 2,080 \\
\hline & $0.7 \%$ & $2.3 \%$ & $0.3 \%$ & $2.5 \%$ & $2.0 \%$ & $1.2 \%$ & $1.0 \%$ & $1.2 \%$ \\
\hline \multirow{2}{*}{1} & 37 & 62 & 27 & 126 & 51 & 11,320 & 346 & 11,969 \\
\hline & $5.0 \%$ & $6.3 \%$ & $9.2 \%$ & $7.1 \%$ & $8.4 \%$ & $7.2 \%$ & $4.7 \%$ & $7.1 \%$ \\
\hline \multirow{2}{*}{$2-4$} & 56 & 112 & 40 & 290 & 78 & 24,080 & 607 & 25,263 \\
\hline & $7.5 \%$ & $11.3 \%$ & $13.7 \%$ & $16.4 \%$ & $12.8 \%$ & $15.4 \%$ & $8.2 \%$ & $15.0 \%$ \\
\hline \multirow{2}{*}{$5-9$} & 53 & 72 & 17 & 179 & 28 & 16,060 & 412 & 16,821 \\
\hline & $7.1 \%$ & $7.3 \%$ & $5.8 \%$ & $10.2 \%$ & $4.6 \%$ & $10.2 \%$ & $5.6 \%$ & $10.0 \%$ \\
\hline \multirow{2}{*}{$10-24$} & 29 & 37 & 13 & 74 & 22 & 10,620 & 288 & 11,083 \\
\hline & $3.9 \%$ & $3.7 \%$ & $4.4 \%$ & $4.2 \%$ & $3.6 \%$ & $6.8 \%$ & $3.9 \%$ & $6.6 \%$ \\
\hline \multirow{2}{*}{25 or more } & 7 & 17 & 5 & 15 & 2 & 2,960 & 107 & 3,113 \\
\hline & $0.9 \%$ & $1.7 \%$ & $1.7 \%$ & $0.9 \%$ & $0.3 \%$ & $1.9 \%$ & $1.4 \%$ & $1.8 \%$ \\
\hline \multirow{2}{*}{ NA } & 560 & 666 & 190 & 1,036 & 415 & 89,880 & 5,593 & 98,340 \\
\hline & $75.0 \%$ & $67.3 \%$ & $64.9 \%$ & $58.7 \%$ & $68.3 \%$ & $57.3 \%$ & $75.3 \%$ & $58.3 \%$ \\
\hline \multirow{2}{*}{ Total } & 747 & 989 & 293 & 1,764 & 608 & 156,840 & 7,428 & 168,669 \\
\hline & $100.0 \%$ & $100.0 \%$ & $100.0 \%$ & $100.0 \%$ & $100.0 \%$ & $100.0 \%$ & $100.0 \%$ & $100.0 \%$ \\
\hline
\end{tabular}

Source: Statistics Denmark, own calculation. 
Table 4: Number of Family Businesses by Turnover and Owner's Country of Origin, 2002 (DKK) $(\mathrm{N}=174,934)$

\begin{tabular}{|c|c|c|c|c|c|c|c|}
\hline Turnover (DKK) & Iran & Pakistan & $\begin{array}{c}\text { Former } \\
\text { Yugoslavia }\end{array}$ & Turkey & China ea. & Denmark & Total \\
\hline \multirow{2}{*}{$0-500,000$} & 170 & 105 & 83 & 455 & 156 & 25,140 & 26,109 \\
\hline & $33.7 \%$ & $13.4 \%$ & $22.9 \%$ & $26.3 \%$ & $23.5 \%$ & $14.7 \%$ & $14.9 \%$ \\
\hline \multirow{2}{*}{500,000 - 999,999 } & 163 & 201 & 94 & 536 & 229 & 25,470 & 26,693 \\
\hline & $32.3 \%$ & $25.7 \%$ & $26.0 \%$ & $30.9 \%$ & $34.5 \%$ & $14.9 \%$ & $15.3 \%$ \\
\hline \multirow{2}{*}{$1,000,000-1,999,999$} & 86 & 226 & 66 & 393 & 128 & 35,650 & 36,549 \\
\hline & $17.1 \%$ & $28.9 \%$ & $18.2 \%$ & $22.7 \%$ & $19.3 \%$ & $20.9 \%$ & $20.9 \%$ \\
\hline \multirow{2}{*}{$2,000,000-4,999,999$} & 57 & 202 & 70 & 236 & 105 & 49,360 & 50,030 \\
\hline & $11.3 \%$ & $25.8 \%$ & $19.3 \%$ & $13.6 \%$ & $15.8 \%$ & $28.9 \%$ & $28.6 \%$ \\
\hline \multirow{2}{*}{$5,000,000$ or more } & 28 & 48 & 49 & 112 & 46 & 35,270 & 35,553 \\
\hline & $5.6 \%$ & $6.1 \%$ & $13.5 \%$ & $6.5 \%$ & $6.9 \%$ & $20.6 \%$ & $20.3 \%$ \\
\hline \multirow[t]{2}{*}{ Total } & 504 & 782 & 362 & 1,732 & 664 & 170,890 & 174,934 \\
\hline & $100.0 \%$ & $100.0 \%$ & $100.0 \%$ & $100.0 \%$ & $100.0 \%$ & $100.0 \%$ & $100.0 \%$ \\
\hline
\end{tabular}

Source: Statistics Denmark, own calculation.

Table 5: Immigrant owned firms (five immigrant groups) by geographical location and business line.

\begin{tabular}{|c|c|c|c|c|c|c|}
\hline \multirow[b]{2}{*}{ Restaurants } & \multicolumn{2}{|c|}{ Central Copenhagen } & \multicolumn{2}{|c|}{ Suburb } & \multicolumn{2}{|c|}{ Province } \\
\hline & 220 & $5.9 \%$ & 92 & $5.4 \%$ & 484 & $7.7 \%$ \\
\hline Cafeteria, barbeques etc. & 432 & $11.6 \%$ & 199 & $11.7 \%$ & 1126 & $18.0 \%$ \\
\hline Food \& Nutrition & 419 & $11.3 \%$ & 121 & $7.1 \%$ & 249 & $4.0 \%$ \\
\hline Supermarkets, Kiosks etc. & 428 & $11.5 \%$ & 143 & $8.4 \%$ & 274 & $4.4 \%$ \\
\hline Special Retail Shops & 300 & $8.1 \%$ & 84 & $5.0 \%$ & 416 & $6.6 \%$ \\
\hline Trade \& Agencies etc. & 227 & $6.1 \%$ & 130 & $7.7 \%$ & 474 & $7.6 \%$ \\
\hline Cleaning & 88 & $2.4 \%$ & 45 & $2.7 \%$ & 107 & $1.7 \%$ \\
\hline Transportation & 174 & $4.7 \%$ & 143 & $8.4 \%$ & 97 & $1.5 \%$ \\
\hline Service & 618 & $16.6 \%$ & 270 & $15.9 \%$ & 861 & $13.8 \%$ \\
\hline Manufacturing & 69 & $1.9 \%$ & 31 & $1.8 \%$ & 232 & $3.7 \%$ \\
\hline Others/NA & 737 & $19.9 \%$ & 438 & $25.8 \%$ & 1,940 & $31.0 \%$ \\
\hline Total & 3,712 & $100.0 \%$ & 1,696 & $100.0 \%$ & 6,260 & $100.0 \%$ \\
\hline
\end{tabular}

Source: Statistics Denmark, own calculation.

Table 6: "How did you finance the purchase of your business? (Make a priority by using $1,2,3, \ldots$, depending on the size of the amount used)"

\begin{tabular}{lcccccc}
\hline & Iran & Pakistan & $\begin{array}{c}\text { Former } \\
\text { Yugoslavia }\end{array}$ & Turkey & China ea. & Total \\
\hline Own saving & $76.8 \%$ & $83.3 \%$ & $84.8 \%$ & $70.5 \%$ & $68.4 \%$ & $76.3 \%$ \\
Loan in Bank and/or Financial Institutions & $33.3 \%$ & $39.6 \%$ & $45.7 \%$ & $48.7 \%$ & $23.7 \%$ & $39.4 \%$ \\
Loan or Gift from Family or Friends & $58.0 \%$ & $54.2 \%$ & $41.3 \%$ & $64.1 \%$ & $71.1 \%$ & $58.1 \%$ \\
Number of Respondents & $\mathbf{6 9}$ & $\mathbf{4 8}$ & $\mathbf{4 6}$ & $\mathbf{7 8}$ & $\mathbf{3 8}$ & $\mathbf{2 7 9}$ \\
\hline
\end{tabular}

Source: Survey Data

The majority of immigrant firms in Denmark are small whether measured by the number of employees or by turnover. According to the figures available, only about $12 \%$ of the private immigrant firms have 5 or more employees (see table 3), and only some $20-30 \%$ of immigrant owned firms have a turnover above 2.000.000 DKK (app. 350.000 US\$) in comparison with the Danish businesses where the number is almost $50 \%$ (table 4). Table 3 must be read with caution though, due to the high number of NA values. 
Table 4 shows the distribution of turnover by the country of origin of the business owners. The main result here is that there is significant variation between the five groups. While only $39,1 \%$ of the Pakistani owned firms and $48,9 \%$ of the firms owned by people from the former Yugoslavia have a turnover below 1.000 .000 DKK, close to $70 \%$ of the Iranian, Turkish and Chinese owned firms fall in this category. The same can be seen on the opposit end of the scale. More than $30 \%$ of the Pakistanis and Ex-Yugoslavians have a turnover above 2.000.000 DKK.

Iranians have low levels of turnover as well as incomes. One important reason could be their much shorter duration of stay in Denmark.

As argued in the 2nd passage the actual location of the firm have importance for break out opportunities. In the following we will caste a glance on this in a Danish context.

\section{GEOGRAPHICAL LOCATION OF IMMIGRANT BUSINESSES}

Immigrant businesses are located throughout Denmark, with concentrations around the big cities. There are significant variations between the groups of immigrant businesses.

Iranians follow the general picture, with businesses located throughout Denmark, and a concentration around the big cities. For Pakistanis, the picture is quite different. Their businesses are almost entirely located in the greater Copenhagen area. The Ex-Yugoslavians differ from the other groups by locating their businesses in the greater Copenhagen area and in the municipality of Helsingør in North-Zealand. Turks follow the general picture with representation throughout the country, but with a tendency of higher concentrations around the island of Zealand.

Table 5 show some differences for immigrant business located in Central Copenhagen, its suburbs and the province. According to table 5 the share of businesses in traditional business lines is slightly lower in Central Copenhagen than in the suburbs and the province ( $19.9 \%$ in proportion to $25,8 \%$ and $31 \%$ ). The province is characterised by a high share of businesses in some of the traditional business lines, particularly restaurants and cafeterias, barbeques, etc., but also with a low share in the retailing business lines. These differences may be understood as a result of weak tendency of breaking-out in the capital.

\section{BUSINESS OWNERS' FINANCIAL NETWORKS}

Table 6 is based on a survey showing answers to the question: "How did you finance the purchase of your business? Multiple answers are allowed for this question, which means that the column percentages do not add up to 100 per cent. 13 different categories could be chosen, here only the three most common categories are presented. The three selected categories are: 1. Own saving, 2. Loan in Bank and/or Financial Institutions and 3. Loan or Gift from Family or Friends.

Table 6 shows that while "Own saving" is the most frequent source of financing the purchase of businesses owned by these five immigrant groups, "Loan in Bank and/or Financial Institutions" is the least used source, (this is however unlike the native Danish business owners). One of the reasons here could be due to the unwillingness of established banks and financial institutions to take risks in approval of loans. A possible obstacle for immigrant entrepreneurs to obtain break out is their limited use of banks and other financial institutions when it comes to financing their businesses. Family and other close relations who lend money to entrepreneurs might have specific wishes for which business line the entrepreneur should start up. This to secure the repayment of the loan. In practice this might mean that the most innovative entrepreneurs are confined in specific business lines.

Immigrants' lack of financial resources to form businesses can possibly be overcome through Rotating Credit Associations ${ }^{[8]}$. Using the Rotating Credit Associations (RCA's) model enables immigrants to achieve a large sum for investment through collective pooling. Geerts describes RCA's as follows:

"A lump sum fund composed of fixed contributions from each member of the association is distributed, at fixed intervals and as a whole, to each member in turn.

Whether the fund is in kind or cash; whether the order the members receive the fund is fixed by lot, by agreement, or by bidding; whether the time period over which the society runs is many years or a few weeks; whether the sums involved are minute or rather large; whether the members are few or many; and whether the association is composed of urban traders or rural peasants, of men or women, the general structure of the institution is the same"[9].

Such a model naturally presupposes the existence of trust between the members ${ }^{[10]}$ and some kind of sanctions and back-up system in case one or more members fail to make their contributions. Such trust is often present within families, but the model is also used in a broader way, e.g. by immigrants from the same locality or region in their home countries ${ }^{[11]}$. Our data indicates that the awareness of the RCA-system is high and increasing among immigrants. A different financial system grounded on different priorities can motivate or de-motivate certain types of financial transactions and investment, by the fact the scope for such activities is often much broader than those offered by financial institutions of the host country. 


\section{BUSINESS OWNERS' SOCIAL NETWORKS}

The social networks immigrant entrepreneurs take part in are of vital importance for their chances to break out. Previous research ${ }^{[12]}$ has shown that access to mono-ethnic social networks is essential when it comes to the possibilities to borrow money for starting a firm. On the other hand access to the natives leads to an opportunity to break out for example when it comes to sharing information on the mainstream market. According to Light:

"Strong ties and start-ups depend upon ethnic background, but information retrieval and break-out require class resources. A mixture of class and ethnic resources may be the best overall endowment, but, of course, neither start-up nor break-out is an overall process. Both happen at discrete moments in time -- so it matters which resources are available when."

Thus the network relationships of the business owners were a central aspect of the survey investigation. The questionnaire contained several questions covering different kinds of business owner network relationships. Results from the answers of two of these questions are presented in this section.
Fig. 1 illustrates the distribution of answers to the question: "Who Gives You Advice When Taking Important Business Decisions "

This and similar questions were constructed in such a way, that the answers were sub-divided into two parts. One part gives the names of individuals. The other part reveals the individual's relationship to the respondent. The respondent is allowed to refer to a maximum of five named individuals.

The method used for generating the basis-data for figure 1 consisted of computing the average number of individuals within five categories of relationships. This average can theoretically range from 0 to 5 . The maximum observed average is 0.83 (for the Iranian/Relatives cell in the cross-tab of figure 1). The maximum scale value of all diagrams inside figure 1 is 1.00. This scale maximum value has been chosen due to graphical presentation only.

A regular pentagon shaped area indicates a diverse network where no single category of relationships is more important than others. If the point of one angle of the shape is sharply skewed in one direction, it means that the category pointed at plays a more significant role.

Fig. 1: Graphical illustration of an average number of persons in five network relationship categories of business owners $(\mathrm{N}=279)$. Based on answers to the question: "Who Gives You Advice When Taking Important Business Decisions?"
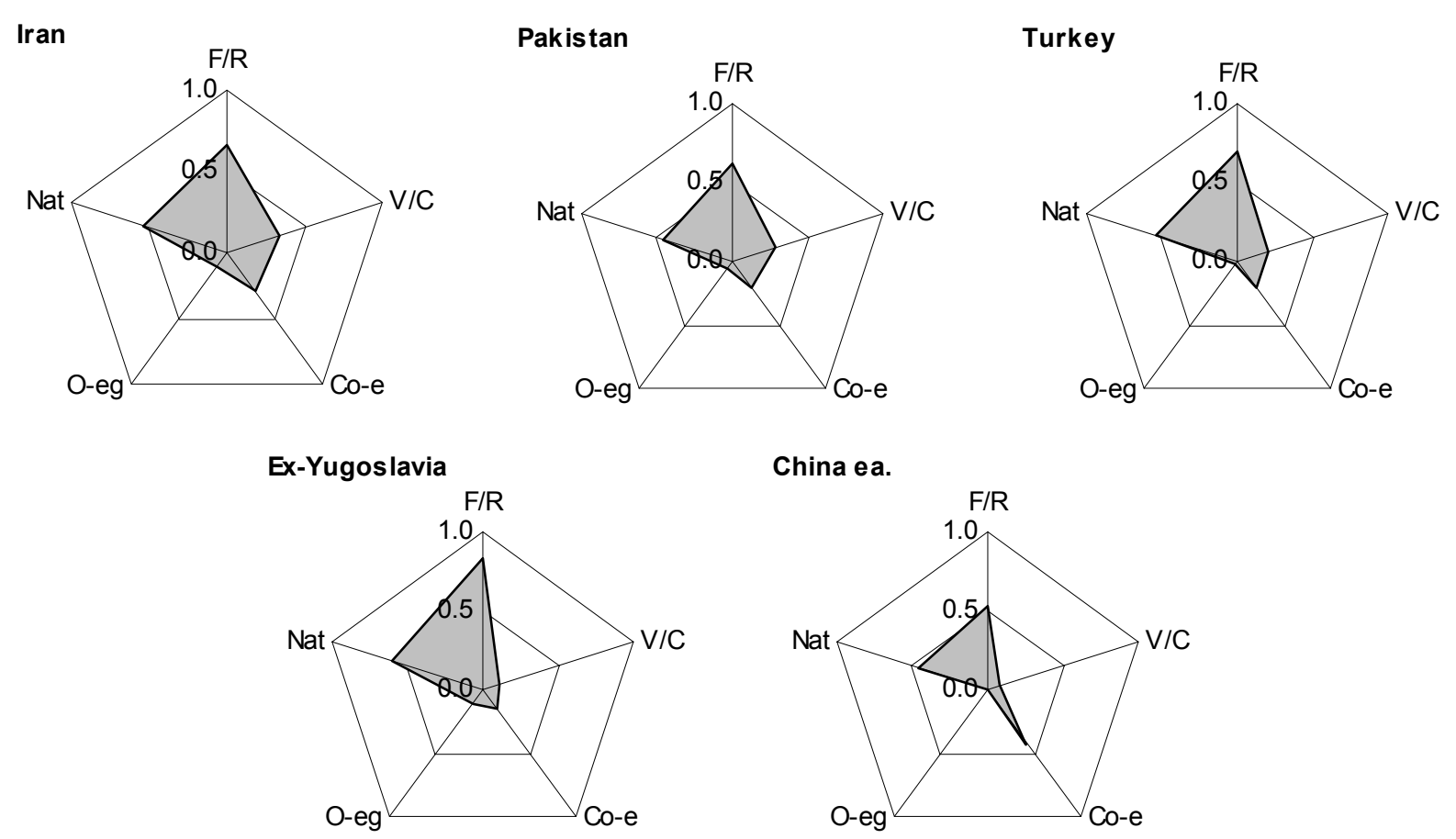

China ea.

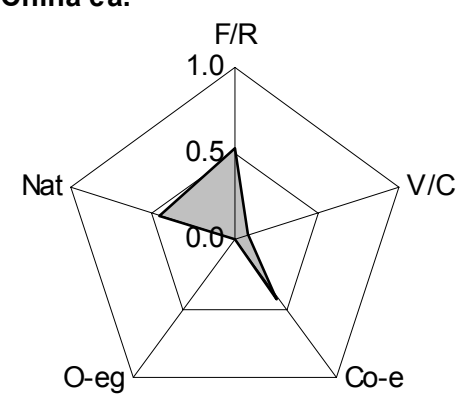




\begin{tabular}{|c|c|c|c|c|c|c|}
\hline & & $\begin{array}{c}\text { Former } \\
\text { Yugoslavia }\end{array}$ & Pakistan & Turkey & Iran & China ea \\
\hline $\mathrm{F} / \mathrm{R}$ & Friends or Relatives & 0.83 & 0.63 & 0.69 & 0.67 & 0.53 \\
\hline $\mathrm{V} / \mathrm{C}$ & $\begin{array}{l}\text { Other (None Relatives) From the same } \\
\text { Town/Village in your Country of Origin }\end{array}$ & 0.11 & 0.29 & 0.21 & 0.33 & 0.08 \\
\hline Co-e & Others From the Same Country & 0.15 & 0.21 & 0.22 & 0.29 & 0.42 \\
\hline O-eg & Minorities From Other Countries & 0.11 & 0.06 & 0.01 & 0.10 & 0.00 \\
\hline Nat & Native Danes & 0.61 & 0.46 & 0.54 & 0.55 & 0.45 \\
\hline
\end{tabular}

Source: Survey data

Table 7: Change from "typical immigrant business line" in 1997 to "typical mainstream business line" in 2002, for people who hold a firm both years $(\mathrm{n}=72.217)$

\begin{tabular}{|c|c|c|}
\hline \multicolumn{2}{|r|}{ Parameter } & \multirow{2}{*}{$\begin{array}{r}\text { Estimate } \\
-3.332^{* * *}\end{array}$} \\
\hline Intercept & & \\
\hline \multirow{7}{*}{ Country of origin } & Other countries (offset) & \\
\hline & Denmark & $-0.405 *$ \\
\hline & Turkey & $1.654 * * *$ \\
\hline & China ea. & $1.086 * * *$ \\
\hline & Pakistan & $1.190 * * *$ \\
\hline & Iran & $1.189 * * *$ \\
\hline & Former Yugoslavia & 0.922 \\
\hline \multirow{2}{*}{ Municipality } & Low percentage of immigrants and descendants (offset) & \\
\hline & High percentage of immigrants and descendants & $-0.142 * * *$ \\
\hline \multirow{4}{*}{$\begin{array}{l}\text { From } 1997 \text { to } 2002 \text { : } \\
\text { Increase in }-(\text { offset }=\text { no } \\
\text { increase) }\end{array}$} & 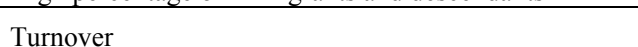 & $-1.628 *$ \\
\hline & Profit & $0.362 * * *$ \\
\hline & Sum of Assets & $0.594 * * *$ \\
\hline & Own capital & 0.159 \\
\hline \multirow{2}{*}{ Citizenship } & Foreign (offset) & \\
\hline & Danish & 0.195 \\
\hline \multirow{7}{*}{$\begin{array}{l}\text { Level of highest degree of } \\
\text { education }\end{array}$} & Primary & -0.224 \\
\hline & Secondary & $0.687 * *$ \\
\hline & Upper secondary & -0.142 \\
\hline & Short Higher education & $-1.297 * * *$ \\
\hline & Medium Higher Education & $9.799 * * *$ \\
\hline & Long Higher Education & 0.293 \\
\hline & Not reported (offset) & \\
\hline \multirow{2}{*}{ Place of education } & Abroad (offset) & \\
\hline & Denmark & -0.075 \\
\hline
\end{tabular}

Source: Statistics Denmark, own calculation, ${ }^{*} * * \mathrm{p}<0.001,{ }^{*} \mathrm{p}<0.01,{ }^{*} \mathrm{p}<0.05$

An example of such a skewed distribution is illustrated in figure 1 for Iranian business owners, where two categories of relationships ("Family/Relatives" and "Native Danes") proved significantly more important than the remaining three, when these respondents make business decisions. Out of the five groups, Iranians have the most balanced pattern of relationships, approximating the pentagon shape.
Even though all groups have high averages when it comes to including natives in their business networks probably because all immigrant groups frequently obtain advice from native Danes (e.g. accountants) when they make decisions - it seems like especially the Ex-Yugoslavians have advantages when it comes to business contact with Danes. This implies that it should be easier for the Ex-Yugoslavians to obtain break out than for other immigrant groups. 


\section{BREAKING-OUT DETERMINANTS}

To investigate which determinants have had impact on breaking out possibilities for firms that were in business in 1997 and were still active in 2002, table 7 shows the results of a logistic regression-analysis of business line changes based on quantitative longitudinal registry micro-data. The model is operationalised so that the dependent variable is a binary one: The business line of a business owner's firm in 1997 is compared with the business line of that same person's firm in 2002. If a change in business line has occurred over this period, the value of the dependent variable is set to 1 . If no change has taken place, the value is set to 0 .

The estimates shown in table 7 refer to the possibility of a business line change having taken place, given 1) the national origin of the business owner, 2) the concentration level of immigrants and descendants in business owner's residential area in 2002, 3) the increase or decrease in certain economic key figures from 1997 to 2002 , 4) his/her citizenship status in 1997 , his/her highest degree of education and finally whether his/her education was obtained in Denmark or abroad.

Studying the figures in table 7 more closely, reveals that immigrants and descendants from Turkey are more likely to change from a marginalized business line to another than immigrants from other countries.

Another look at table 7 shows that immigrants and descendants who owned a firm that had had an increase in turnover are less willing to change business line, than firm owners who had a decrease in this. The opposit is the case for business owners who had an increase in sum of assets or profit. An obtained Danish citizenship does not seem to have much importance on the possibility to change business line, but the degree of education does seem to have something to say on that matter. It can be seen that business owners with a medium long education have a marked positive difference when it comes to change from typical immigrant business line to a mainstream business line. It might seem surprising that this is not the case for respondents with Long Higher Education, but a fair explanation for this is the preference for employment instead of entrepreneurship for this group.

All in all the table shows that within the available variables one of the most important factors for break out for ethnic businesses is the level of education for the business owner. Though it must be held in consideration that important factors - such as the social and financial networks the business owners interact in were not among the available variables for the shown model.

\section{THE DENSITY OF INTER-ETHNIC RELATIONSHIPS RELATIVE TO INTRA-ETHNIC ONES}

Close intra-ethnic relationships is the key indicator of immigrant businesses in deprived immigrant areas as well as in prospering business enclave areas. Immigrant business owners tend in such areas to give priority to transactions with co-ethnics, as customers, employees and business partners, because of intense information flows, easy communication and trust building background institutions within these groups. This makes negotiating a business contract and joint action easier with a co-ethnic than with other people.

Strong intra-ethnic relationships usually correlate with weak ties to other ethnic groups, including the majority population. Upon arrival in their new countries all immigrants suffer from an information and knowledge gap, but some groups catch up more quickly than others through search, interaction and learning processes. Running a business is one way of catching up, usually leading immigrants into action-learning processes through which they discover the secrets of their new society. However, even business owners may sometimes have only limited interaction with the majority population. This is quite understandable in local areas with a dominant ethnic group, but it also occurs in some immigrant businesses in majority dominated areas where the need for communication and interaction with the majority population is marginal. Other types of businesses, however, simply cannot be run without intense interaction with the majority population.

The shaping of intra-ethnic and inter-ethnic relationships does not correlate with breaking-out processes unambiguously. Ethnic business enclaves illustrate that firms may start growing and prospering based on a dominance of intra-ethnic networks, but it seems to be the exception rather than the rule. In Denmark and other European countries where immigrants gather in multi-ethnic inner city areas rather than mono-ethnic zones, relating to other ethnic groups, including the majority population, seems to be a safer road to breaking-out than the intra-ethnic strategy.

The Chinese and Iranian business owners in Denmark illustrate this point. Chinese business owners seem characterised by limited communication and interaction with other ethnic groups. They have, like the Chinese in most other European countries ${ }^{[14]}$, specialised strongly in the catering and restaurant businesses and hence are running businesses all over the country. Nevertheless they remain quite isolated from the majority population and other immigrant groups. This may explain why this group, which in other parts of the world is known to be entrepreneurial, was not able to use its first mover advantage in the ethnic restaurant field and the resultant high profits in the 1960s and 1970s to establish larger and more profitable businesses in other sectors, in spite of increased competitive pressure and consequent income squeeze during the 'eighties and 'nineties.

\section{THE IMPORTANCE OF COMPETENCIES}

In order to run a business in a foreign country, an immigrant need both general competencies achieved through formal education, business competencies, which are both of a general nature and sector specific, and cultural competencies to interact and negotiate with the majority population and its businesses and institutions.

The impact of the three types of qualifications: general, business and cultural, on immigrant businesses 
and breaking-out processes is ambiguous. In business areas with low demands for general qualifications, an advanced educational level may be a hindrance to success rather than the opposite, in that owners in such cases may be running businesses in which they are not truly interested and committed because they do not correspond to their educational level and aspirations. In knowledge intensive business areas a high educational level is a must. While formal education is only imperative for some businesses, business experience and talent as well as cultural competences is important in all business areas.

The ambiguous impact of qualifications on immigrant business was revealed in the Danish data on Iranian business owners who are by far the most welleducated of the five immigrant groups, usually educated in Denmark and speaking Danish fluently, but at the same time also a group who themselves perceive a wide gap existing between their current business competencies and the needed ones, and was also the group which had the lowest per capita income in 1996 (see table 1). One possible explanation for this paradox is their limited business experience, but weak motivation may also be part of the explanatory pattern. In cases where they never aspired to become selfemployed, choosing this path because they could not find employment that corresponded their social capital, they may well "break-out" by becoming employees rather than by attempting to establish new businesses outside the traditional immigrant business sectors.

The overall pattern of qualifications amongst immigrant business owners in Denmark indicates a limited potential for breaking-out for the huge majority of the present business owners who suffer from low qualification levels. They work hard, but they do not have the potential of breaking-out in a society in which qualification standards increase rapidly. The exception from this pattern is the well-educated first generation immigrants and the growing number of well-educated second generation immigrants who are searching for a role in economic life as business owners. A major process in which businesses shift hands from parents to children started during the 1990s, particularly for business owners of Turkish and Pakistani descent. This is likely to lead to the setting up of more businesses outside the traditional immigrant business sectors.

\section{FINANCIAL RESOURCES}

It seems reasonable to assume that there is a close connection in the relationship between financial resources and breaking-out potential. One of the main reasons why immigrant businesses tend to cluster in certain areas and business lines is low entrance barriers. Immigrant business owners seeking to break-out should therefore normally expect higher entrance barriers in other fields, which usually implies the need for more financial resources. An additional reason why some Iranian first generation immigrants and Turkish and Pakistani second generation immigrants may succeed in breaking-out is the financial resources they have access to through their families. Many Iranian immigrants come from wealthy families and second generation
Turkish and Pakistani immigrants may benefit from the resources their parents have succeeded in accumulating during their careers as business owners.

\section{CROSS BORDER BUSINESS RELATIONS}

Cross border business relations are often an inherent characteristic of immigrant businesses. Immigrant business owners frequently run business activities in their countries of origin, but they may also link up with co-ethnic immigrants in other countries, or their businesses may be sufficiently strong to expand to other countries as with any ordinary business. The latter option is still rare in countries like Denmark with a short history of immigrant businesses, but increasingly found in countries with a richer experience such as the USA and Britain. The dominant form of cross border relations is small scale and person driven bi-country business activity, but some larger units are also found. For some ethnic commodities there are room for immigrant owned businesses of a medium or large size as key players in ethnic commodity chains such as importers and wholesalers in a number of countries. Moreover, the growing number of immigrant business firms opens up business options for specialised service institutions such as accounting and financial ones, even at the international level.

\section{CONCLUSIONS}

The focus of this paper has been on breaking-out processes from immigrant dominated business lines, using the Danish situation as its empirical basis. Most immigrant businesses in Denmark and elsewhere are small family owned firms, of which the huge majority do not grow, restructure and relocate. But some do, and the paper aims at improving our understanding of this process taking departure in the model of immigrant business breaking-out by Ram and Jones.

The empirical section was based on longitudinal registry data and a survey among immigrant business owners from 1999, both of which were structured in a way that allowed comparison between five immigrant business owner groups, coming from Pakistan, the former Yugoslavia, Turkey, Iran and China.

The empirical data demonstrated that for all the compared immigrant groups the average gross-income is lower for self-employed than for wage earners. And that the bulk of immigrant firms are, and remain, small family units within traditional immigrant business lines such as small retail shops, restaurants and fast food outlets. Only about 12 per cent of the firms have more than 5 employees (of which about 80 per cent were from the Danish majority).

It also showed that all the groups took advice from native Danes when taking important business decisions. A number that must be guarded with care as all businesses in Denmark are obliged to a yearly revision by an authorised accountant.

A statistical regression analysis of the position of firms within business lines in the period 1997-2002 indicated some breaking-out tendencies: an increasing 
number of firms are being established outside the traditional immigrant business lines. It also showed that the most important factor among the variables was the owners' educational level.

Of the five groups, Iranian business owners seem to have the highest potential for breaking-out as their level of education is far above that of the other groups. Moreover, they have more pluralistic networks than the other groups, with close contact to other ethnic groups, and relatively frequent investments in their country of origin. An explanation of why Iranians have a lower degree of change in business line than the other groups is possibly their partiality for employment according to their level of education.

Also, the growing number of second generation business owners, mainly of Pakistani and Turkish descent, seem to have a potential for breaking-out as they generally are well-educated and often have funds for investment from their parents. It should be stressed, however, that breaking-out is still a rare phenomenon in Denmark.

This empirical evidence and the lessons from some other countries such as the USA and Britain ${ }^{[15]}$ led us to suggest four breaking-out determinants: (1) the degree of density in inter-ethnic relationships relative to intraethnic ones, (2) the level and composition of competencies (general, business and cultural), (3) financial resources, and (4) cross border business relations. In others words, immigrant business owners with close contacts to other ethnic groups (including the majority population), with an advanced and broad competence profile, with financial resources (often derived from family sources), and with cross border business relations, are the ones who are most likely to develop firms that grow, restructure and relocate, i.e. breaking-out firms.

\section{REFRENCES}

1. Rezaei, S., \& Goli, M., 2005, "Indvandreres tætte netværk: Katalysator eller hæmsko for innovation og vækst? - Et studie af formelle og uformelle netværksrelationers betydning for dynamikken $\mathrm{i}$ indvandrerejede virksomheder", Delrapport 1: Selverhvervende indvandrere - Vilkår, Potentialer., Udarbejdet for Erhvervs- og Byggestyrelsen, September 2005, Roskilde Universitetscenter.

2. Sheffer, G., 2003, "Diaspora Politics: At Home Abroad", Cambridge University Press, Cambridge \& New York.

3. Banton, M., 1996, National Variation in Conceptions of Racism, Paper presented at Eurofor Conference No. 14, Sandbjerg, Denmark.

4. Waldinger, R., H. Aldrich, R. Ward, and Associates 1990: Ethnic entrepreneurs: Immigrant business in industrial societies. Newbury Park, CA: Sage.

5. Aldrich, H., J. Cater, T. Jones, D. McEvoy, P. Velleman 1995: Ethnic residential concentration and the protected market hypothesis. Social Forces, 63/4: 996-1009.
6. Zimmer, C., H. Aldrich 1987: Resource mobilization through ethnic networks: Kinship and friendship ties of shopkeepers in England. Sociological Perspectives, 30: 422-445.

7. (Barrett, et al. 1994xxx. Ram, M., T. Jones 1998: Ethnic minorities in business. Small Business Trust, Open University p: 794.

8. Basu, A. 1999: Growth strategies of South Asian entrepreneurs in Britain (unpublished paper to Rent XIII Conference, Nov. 1999) p: 5.

9. Ong, P., E. Bonacich, L. Cheng 1994: The new Asian immigration in Los Angeles and global restructuring. Philadelphia: Temple Press p: 20.

10. Yu Zhou 1998: Beyond ethnic enclaves: Location strategies of Chinese producer service firms in Los Angeles. Economic Geography, 74/3: 228-251.

11. Ram, M., T. Jones 1998: Ethnic minorities in business. Small Business Trust, Open University.

12. Light, I., G. Sabagh, M. Bozorgmehr, C. DerMartrosian 1994: Beyond the ethnic enclave economy. Social Problems, 41: 65-80.

13. Bager, T. 1998: Migrants as carriers of institutional and organisational forms. Papers, migration No. 28, Danish Centre for Migration and Ethnic Studies. Esbjerg: South Jutland University Press.

14. Geerts, C. 1962: The rotating credit association: a "middle-rung" in development, Economic Development and Cultural Change, 10(3), pp.241261.

15. Geerts, C. 1962: The rotating credit association: a "middle-rung" in development, Economic Development and Cultural Change, 10(3), pp.241261 p: 243.

16. Bager, T. 1998: Migrants as carriers of institutional and organisational forms. Papers, migration No. 28, Danish Centre for Migration and Ethnic Studies. Esbjerg: South Jutland University Press.

17. Rezaei, S. 2005 "Det duale arbejdsmarked $i$ et velfoerdsstatsligt perspektiv - et studie af dilemmaet mellem uformel økonomisk praksis og indvandreres socioøkonomiske integration", University of Roskilde.

18. Light, I., The Ethnic Economy, 2005 in Neil Smelser and Richard Swedberg, Handbook of Economic Sociology, 2d edition, pp. 650-678, New York: Russell Sage Foundation.

19. Benton, G., F.N. Pieke (eds) 1998: The Chinese in Europe. MacMillan, London.

20. For example Light, I., S. J. Gold 2000: Ethnic economies. New York: Academic Press. Barrett, G.A., Jones, T.P. and McEvoy, D.1996 Ethnic minority business: theoretical discourse in Britain and North America, Urban Studies, 33, p. 793, and Ram, M., T. Jones 1998: Ethnic minorities in business. Small Business Trust, Open University, or Basu, A. 1999: Growth strategies of South Asian entrepreneurs in Britain (unpublished paper to Rent XIII Conference, Nov. 1999) p: 5 